\title{
BIOLOGICAL AND LAND ASSETS IN AGRICULTURE: DEVELOPMENT ISSUES OF ACCOUNTING AND MEASUREMENT"
}

\section{Rolan A. ALBOROV ${ }^{\mathrm{a},}$, Svetlana M. KONTSEVAYA ${ }^{\mathrm{b}}$, Svetlana V. KOZMENKOVA ${ }^{\mathrm{c}}$}

\author{
${ }^{a}$ Izhevsk State Agricultural Academy (Izhevsk SAA), Izhevsk, Udmurt Republic, Russian Federation \\ udtipb@yandex.ru \\ ORCID: not available \\ ${ }^{\mathrm{b}}$ Izhevsk State Agricultural Academy (Izhevsk SAA), Izhevsk, Udmurt Republic, Russian Federation \\ kafedra.byfa@yandex.ru \\ ORCID: not available
}

c National Research Lobachevsky State University of Nizhny Novgorod (UNN), Nizhny Novgorod, Russian Federation skozmenkova@yandex.ru

ORCID: not available

- Corresponding author

\section{Article history:}

Received 25 July 2019

Received in revised form 25 July 2019

Accepted 25 July 2019

Available online

30 September 2019

JEL classification: M41

Keywords: land assets, biological assets, accounting, valuation, agriculture

\begin{abstract}
Subject This article discusses the development of accounting and evaluation of biological and land assets in agriculture.

Objectives The article aims to justify the conceptual provisions of accounting and evaluation of biological and land assets in agriculture and develop recommendations for their proper accounting.

Methods For the study, we used the methods of analysis, comparison, classification, and the analog approach.

Results The article defines the conceptual provisions of the development of biological and land assets accounting and provides certain practical recommendations for the methodology and organization of this accounting. The article also offers methods of their evaluation as a basis for calculating fair value.

Conclusions and Relevance Biological and land assets in agriculture are special means of production taking into account their essence, content, specific natural and material form, and the way of use in agricultural activities. The specifics of these assets cause many problems of their accounting on the basis of the draft Federal standards Property, Plant and Equipment and Inventories. The results of the study can be used in the theory and practice of financial accounting.
\end{abstract}

(C) Publishing house FINANCE and CREDIT, 2019

Please cite this article as: Alborov R.A., Kontsevaya S.M., Kozmenkova S.V. Biological and Land Assets in Agriculture: Development Issues of Accounting and Measurement. Digest Finance, 2019, vol. 24, iss. 3, pp. 320-328. https://doi.org/10.24891/df.24.3.320

Agriculture is one of the largest sectors of the Russian economy. The effectiveness of agriculture and agricultural activities of some enterprises depends on numerous factors of intensification, soil, climate, organizational and managerial efforts.

\footnotetext{
"For the source article, please refer to: Алборов P.A., Концевая С.М., Козменкова С.В. Проблемы развития учета и оценки биологических и земельных активов в сельском хозяйстве // Международный бухгалтерский учет. 2019. Т. 22. № 8. C. 859-871. URL: https://doi.org/10.24891/ia.22.8.859
}

Agriculture consists of two major agricultural production sectors, such as horticulture and animal husbandry. Horticulture and animal husbandry, correspondingly, include independent sub-segments operating through any business and legal forms of agricultural enterprises:

1) horticulture: fodder production, grain production, olericulture, pomology, potato growing, industrial crop production, etc.; 
2) animal husbandry: pastoral farming, horse breeding, pig farming, fish farming, fur farming, etc.

What distinguishes the agricultural production in the above segments and sub-segments is the use of biological assets as means and tools of production (living plants and animals) and land assets across types of farmlands (arable land, hayland, pastures, etc.).

Agricultural production employs specific types of tangible and biological subjects of labor (pesticides, mineral fertilizers, agricultural medicines, biological and chemical simulators of product growth, etc.), whose dosage should be strictly controlled to ensure the environmental security. Therefore, it is necessary to conceptualize development principles and methodological aspects of accounting for biological and land assets, agricultural production costs and its quality.

The quality of agricultural products should be accounted for not only in terms of available qualities (fat, protein, feed unit, etc.), but also in terms of harmful substance percentage (nitrites, nitrates, salt of heavy metal, poisons, etc.) in comparison with the scientifically proven and tolerable percentages.

We believe that the conceptual accounting framework for agriculture should primarily define the concept of agricultural activity.

Nowadays, when the world sees the global economy emerging, agriculture and agricultural activity should be qualified as manageable systems (controllable object) at any level of the management process. However, some controllable objects in the agricultural activity, which are also accounting items (agricultural crops, livestock, land plots, agricultural production costs, output, financial results), should be separately carried in books, balance sheet and statement of financial results.

If such items are carried separately in accounts and respective financial reporting forms, the entity should specifically provide for analytical and synthetic accounting for its business operations with respect to the items.
The Russian accounting community in agriculture admitted the need to introduce new namings of assets long ago, such as biological assets (as per IAS 41 - Agriculture ${ }^{1}$ ), land assets, which will require separate synthetic accounts in the first and sector sections of the Chart of Accounts on financial and business operations ${ }^{2}$.

If biological and land assets are carried in separate accounts, agricultural entities will be able to compile all relevant information for accounting and financial reporting purposes to manage the assets and determine the result of their use.

The idea of recognizing the above assets in separate accounts turns out to be even more relevant as National Accounting Regulator Methodological Center for Accounting (Methodological Center for Accounting) releases draft Federal Accounting Standards - Fixed Assets $^{3}$ and Inventories ${ }^{4}$.

Material amendments should also be made to the Rules for Valuation of Biological Assets, Agricultural Products, Tangible and Biological Production Costs, which are applied in the Russian accounting practice of the agricultural sector.

Biological assets and agricultural products are measured at fair value, which is based on the market value prevailing in the active market. If there is no active market in the region (district, area), fair value is measured through the mean cost of acquisition or disposal, domestic transfer price per unit of this type (group) of biological asset, agricultural product.

\footnotetext{
${ }^{1}$ International Accounting Standard (IAS) 41 - Agriculture (as amended, approved in Russia by Order of the Russian Ministry of Finance of June 27, 2016 № 98H, IFRS 16 as approved in Russia by Order of the Russian Ministry of Finance of July 11, 2016 № $111 \mathrm{H}$ )

${ }^{2}$ Order of the Russian Ministry of Finance of October 31, 2000 № 94H (edited as of November 8, 2010 № 142H), On Approval of the Chart of Accounts on Financial and Business Operations and Practical Instructions. URL:

http://www.consultant.ru/document/cons_doc_LAW_29165/d5b75 52984ff633c3f1bbccbc7f9d65e6ad5c76c/ (In Russ.)

${ }^{3}$ Federal Accounting Standard - Fixed Assets (draft). URL: http://bmcenter.ru/files/proekt_fsbu_osnovniye_sredctva (In Russ.)

${ }^{4}$ Federal Accounting Standard - Inventories (draft). URL: http://bmcenter.ru/Files/proekt_FSBU_Zapaci (In Russ.)
} 
To measure biological assets and agricultural products at fair value, it is necessary to modify the accounting approach to output, income, expenses and financial results from agricultural activities, which correspondingly result from biological transformation of biological assets.

The measurement of biological assets at fair value was studied by the Russian and foreign scholars, such as R.A. Alborov, S.M. Kontsevaya, L.I. Khoruzhii ${ }^{5}$ S.M. Kontsevaya, G.R. Kontsevoi, M.K. Dzhikii [1-3], S.V. Bodrikova, E.L. Mosunova, E.V. Zakharova [4], A.F. Dyatlova, F.I. Vas'kin, [5], G.S. Klychova, A.R. Zakirova, A.S. Klychova, L.F. Sitdikova [6], S.V. Kozmenkova, E.N. Shatina ${ }^{6}$, N.S. Nurkasheva, Z.P. Aidynov, M.Zh. Zharylkasinova (Republic of Kazakhstan) [7], A.S. Khusainova [8], E.A. Shlyapnikova, A.V. Vladimirova [9].

Market value, cadastral value or internal basic value should be used to reasonably account for movements of land assets and recognize their availability as of the end of a reporting period in balance sheets of agricultural entities [10, 11]. Market value will work for measurement of land assets, if it is available, while cadastral value and internal basic value per hectare of each agricultural land (asset) should be assessed individually, taking into consideration the quality of land, rent and capitalization ratio.

The appropriate accounting procedure with respect to biological assets measured at fair value requires to clearly define the substance of agricultural activity and concept of biological assets, agricultural products, biological transformation $[1,8]$. Furthermore, it is necessary

\footnotetext{
${ }^{5}$ Alborov R.A., Kontsevaya S.M., Khoruzhii L.I. [Issues of setting standards of accounting for biological assets and agricultural products]. Razvitie ekonomiki, uchetnoanaliticheskikh $i$ kontrol'no-analiticheskikh funktsii upravleniya $v$ APK: materialy Mezhdunarodnoi nauchno-proizvodstvennoi konferentsii [Proc. Int. Sci. Conf. The Development of Economy, Accounting-Analytical and Controlling Analytical Functions of Management in Agri-Industrial Complex]. Izhevsk, Izhevsk State Agricultural Academy Publ., 2018, pp. 31-34.

${ }^{6}$ Kozmenkova S.V., Shatina E.N. [Specifics of applying IAS 41 - Agriculture in the Russian practice of accounting and financial reporting]. Mezhdunarodnyi bukhgalterskii uchet $=$ International Accounting, 2010, no. 16, pp. 2-7. URL: https://cyberleninka.ru/article/n/osobennosti-primeneniya-mbs-ias41-selskoe-hozyaystvo-v-rossiyskoy-praktikeucheta-i-otchetnosti (In Russ.)
}

to specify the classification of products, biological assets and the procedure for their recognition in accounting records at fair value.

We studied the classification of land assets by type of agricultural land in our previous research [12, p. 56], which should be more precise in the current circumstances. We suggest supplementing the traditional classification of agricultural land with land plots designated for ponds in pond fish farming ${ }^{7}$.

To account for production costs in horticulture and animal husbandry, entities should primarily itemize costs, classify production costs in terms of output into four groups:

- exceptionally variable;

- conditionally variable;

- mixed (abrupt);

- exceptionally fixed.

The above groups of costs and their sequence should be referred to when entities outline their detailed namings of accounting items and do planning procedures pursuing the comparability of accounting and planning data.

The conceptual accounting framework for accounting can be used to formulate accounting standards (federal or sectoral) on biological assets and agricultural products, land assets.

However, there should be set up an accounting technique for biological assets and agricultural products to be carried at fair value net of cost to sell. The issues gain traction since the Methodological Center for Accounting released its draft Federal Accounting Standards - Fixed Assets $^{8}$ and Inventories ${ }^{9}$.

According to paragraph 3, subparagraph 'a' of the Federal Accounting Standard - Fixed Assets, this

\footnotetext{
${ }^{7}$ Alborov R.A., Kontsevaya S.M. [Developing the technique to measure and accounting for land assets]. Ekonomika sel'skokhozyaistvennykh i pererabatyvayushchikh predpriyatii = Economy of agricultural and Processing Enterprises, 2013, no. 12 , pp. 29-32. (In Russ.)

${ }^{8}$ Federal Accounting Standard - Fixed Assets (draft). URL: http://bmcenter.ru/files/proekt_fsbu_osnovniye_sredctva (In Russ.)

${ }^{9}$ Federal Accounting Standard - Inventories (draft). URL: http://bmcenter.ru/Files/proekt_FSBU_Zapaci (In Russ.)
} 
standard does not apply to...animals and plants, other than fruit-bearing plants, which are used for agricultural production purposes... This statement raises a question about a regulatory document which agricultural entities should adhere to in their accounting for draught animals and productive livestock after the above standard comes into force. Currently, such items are within the scope of the Accounting Regulation Accounting for Fixed Assets (PBU 6/01) and qualified as fixed assets ${ }^{10}$.

Therefore, we believe that before the draft Federal Accounting Standard - Fixed Assets is put into practice, some amendments should be made to the Russian Classifier of Fixed Assets, labelling biological assets (living plants and animal) as special objects of planning, accounting and management, subdividing them into noncurrent and current biological assets. Non-current biological assets include draught animals and productive livestock and some type of perennial plantings, other than fruit-bearing plants (see IAS 41 - Agriculture). Current biological assets include livestock in farming and fattening, plants, other than fruit-bearers.

Hence, before the draft Federal Accounting Standard - Fixed Assets is introduced and adopted, in addition to the proposed amendments, there should also be a draft federal or sectoral standard - Accounting for Biological Assets and Results of their Biological Transformation. It is reasonable to adopt and enact the draft concurrently with the draft Federal Accounting Standards - Fixed Assets, Inventories.

What else complicates the approval and adoption of the draft federal accounting standard - Fixed Assets is the practice of accounting for noncurrent biological assets, since they will not be attributed to fixed assets. Thus, the Chart of Accounts on financial and business operations of agricultural entities should provide for separate synthetic accounts, such as Non-Current Biological Assets, Depreciation on Non-Current Biological Assets.

\footnotetext{
${ }^{10}$ Accounting Regulation (PBU 6/01) - Accounting for Fixed Assets: approved by Order of the Russian Ministry of Finance of March 30, 2001 № 26H (with amendments). URL: http://www.consultant.ru/document/cons_doc_LAW_31472/ (In Russ.)
}

Accountants have no such difficulties handling current biological assets. Current biological assets will be carried in Accounts 11 - Livestock, 20 Core Production, 97 - Deferred Expenses.

As for accounting for agricultural products measured at fair value net of costs to sell, accountants will face additional difficulties adopting the draft Federal Accounting Standard Inventories. As put in paragraph 25 thereof, agricultural, forestry and fish farming entities... are entitled to measure inventories when they are recognized as assets and at fair value for further accounting periods. This clause means that all types of inventories can measure only those inventories that they produced as agricultural products. Other types of inventories, such as petrochemicals, fuel, mineral fertilizers, spare parts, construction materials, etc., should be measured at their actual value before acquisition (production) $)^{11}$.

To recognize agricultural products at fair value net of costs to sell, accountants should use Account 40 - Output as credit debited to Accounts 43 - Finished Products, 10 - Materials, and as debit credited from Account 20-1 Horticulture, 20-2 - Animal Husbandry. The difference between credit turnover (fair value of agricultural products net of costs to sell) and debit turnover (actual costs to produce agricultural products) of Account 40 can be carried as income (expense) of the period posted to debit of Account 90 Sales (method of supplementing entry, negative posting).

Another challenging issue for agriculture is the technique for accounting and measurement of land assets. This subject is scrutinized in our own studies $^{12}[11,12]$ and by other scholars, such as O.N. Berezinets [13], S.G. Vegera (Republic of Belarus) [14, 15], A.M. Dauzova (Republic of Kazakhstan) [16], E.M. Dusaeva, O.V. Fedorova

\footnotetext{
${ }^{11}$ Accounting Regulation (PBU 5/01) - Accounting for Inventories: approved by Order of the Russian Ministry of Finance of June 9, 2001 № 44H (with amendments).

URL: http://www.consultant.ru/document/cons_doc_LAW_32619/ (In Russ.)

${ }^{12}$ Alborov R.A., Kontsevaya S.M. [Developing the technique to measure and accounting for land assets]. Ekonomika sel'skokhozyaistvennykh i pererabatyvayushchikh predpriyatii $=$ Economy of Agricultural and Processing Enterprises, 2013, no. 12, pp. 29-32. (In Russ.)
} 
[17], G.S. Klychova, A.R. Zakirova, A.S. Klychova [18], L.I. Khoruzhii and A.S. Khusainova [19].

As currently required by the Accounting Regulation (PBU 6/01) - Accounting for Fixed Assets, land plots are carried in Account 01 Fixed Assets. However, it does not clarify which land plots are concerned. Land plots designated for agricultural and non-agricultural use shall not be measured and accounted for on the equal basis. From perspectives of agricultural entities, agricultural land is a core means of production, that is, being concurrently a means of labor and subject of labor [12]. Treating it as a means of labor, land in agriculture is used as space, area. Viewing it as a subject of labor, land is the fertile land cover (top soil) to cultivate agricultural crops and produce agricultural products.

Therefore, in agriculture, agricultural land cannot definitely be posted to fixed assets or inventories. Agricultural entities derive economic benefits from top soil as agricultural products. That is why we believe that agricultural land should be classified as means of production and carried separately as land assets. Consequently, the Chart of Accounts on financial and business operations should feature a separate synthetic account Land Assets. The account can be linked with subaccounts and analytical accounts by type of land assets (pastoral land, layland, hayland, etc.), crop rotation field and plots [12].

Doing so, entities will properly keep accounting records of movements and availability of land assets (for various sources of addition and disposal), transfer as a collateral under a loan contract, addition or transfer under lease or use, reclassification (transformation) of one land type into the other or non-agricultural land into agricultural one (land assets). Hence, financial accounting for land aims to inform users of financial statements on the quantity and value of land, its availability and movements. However, such information shall be of high quality for purposes of effective land management [11, 2022].

In case of various transactions with land plots as items (sale-purchase, lease, pledge, etc.), reasonable valuation becomes very important to use land effectively and reasonably and keep accounting records of land assets properly. Therefore, there should be relevant methods to measure various land assets, which could be used as internal valuation tools and pricing benchmark (baseline) in land deals with external partners (customers).

The income method is the simplest approach to valuation of a hectare of arable land, layland and land plot used for gardening, vineyards. As part of the income method, gross product of horticulture should be determined, net of products of natural hayland and pastures, by hectare of crop farming. All horticulture costs, net of costs for products of natural hayland and pastures, are subsequently divided by land area of crop farming and production costs per hectare of such land are determined. Subtract production costs (PC) per hectare of such crop farming area from gross product (GP) of horticulture and multiply the resultant difference times the number of years of capitalization (C) (payback period) on land value (LVT):

$L V T=(G P-P C) \times C$

$C=100 / R O E$,

where $R O E$ is the return on equity of the entity, or the rate of interest on loan.

Using the above method to measure one hectare of crop farming area, gross product of crop farming (horticulture net of products from natural hayland and pastures) can be assessed by measuring all types of crop farming products:

1) at fair value $[2-4,9]$;

2) at internal accounting prices.

Gross product of horticulture results from the cost of horticulture product and balance of construction-in-progress.

The assessment of gross product (GP) of horticulture can be presented as the following formula:

$G P=H P C+C i P B$

where HPC is the cost of horticulture products;

$C i P B$ is the balance of Construction-in-Progress. 
To measure the fair value of a metric centner of horticulture commodities, the following formula can be used:

$F V i=M i-S C i$

where $F V i$ is fair value of a centner of horticulture product, type $i$, RUB;

$M i$ is market value of a centner of horticulture product, type $i$, RUB;

$S C i$ is costs to sell a centner of horticulture product, type i, RUB.

Measuring the fair value of horticulture products, one should remember that market value is not available for all types of products. For instance, there is no market value of such feedstuff as hay, straw, herbage, haylage, etc. (produced with internal resources). Hence, there are no market benchmarks for them.

Consequently, fair value of certain feedstuff (FVFi) per centner, which is internally produced, can be measured at fair value of a centner of oat or 75 percent of fair value of all grain types per centner:

$F V F i=F V O \times C K E i$

or

$F V F i=F V G \times 0.75 \times F U i$,

where FVO is fair value of oat per centner, RUB;

$F V G$ is fair value of grain per centner, all types, RUB;

$F U i$ is the amount of feedstuff units per centner of i-type of feed, centner of feedstuff unit.

If internal estimated prices (transfer prices) are used to measure horticulture products, the full production cost and the rate of return (loss) on sales of certain types of products should be taken for assessment purposes in such cases:

$T P i=F P C i \times(1 \pm R R S i)$,

where $T P i$ is the estimated price of $i$-type of product, RUB per centner;

$F P C i$ is the full production cost of $i$-type of products, RUB per centner;
$R R S i$ is the rate of return (loss) on sale of $i$-type of products $(\% / 100)$.

The estimated price per centner of a certain feedstuff can be measured through the estimated price per centner of oat or 75 percent of the estimated price per centner of all grain types:

$T P F i=T P O \times T P G i$

or

$T P F i=T P G \times 0.75 \times F U i$,

where $T P F i$ is the estimated price for $i$-type of feedstuff, RUB per centner;

$T P O$ is the estimated price for oat, RUB per centner;

$T P G$ is the estimated price for all grain types, RUB per centner.

To measure the internal cost (price) of a hectate of such a land asset, another technique can be used, considering the quality of land (soil rating) [10]:

$$
\begin{aligned}
L V T & =\text { Price per point } \times \text { Soil Quality Point } \times \\
& \times\left(\frac{W A G O_{F V-T P}}{W A G O_{F U}}-\frac{W A G O_{A V}}{W A G O_{F U}}\right) \times C,
\end{aligned}
$$

where Price per point means the price for a point given for the soil quality of the land asset in question against the gross horticulture output (all types of products) in terms of feedstuff units per hectare, centner per feedstuff, centner of feedsuff;

Soil Quality Point means a point given for the soil quality of such a land asset in an entity, points;

$W A G O_{F V-T P}$ is weighted average gross horticulture output (all types of products) at fair value or internal estimated prices per hectare of agricultural land (land assets), thousand RUB;

$W A G O_{A V}$ is weighted average gross horticulture output (all types of products) at actual cost of production per hectare of agricultural land (land assets), thousand RUB;

$\mathrm{WAGO}_{\mathrm{FU}}$ is weighted average gross horticulture output (all types of products) as feedstuff units per hectare of agricultural land (land assets), centner per feedstuff unit. 
This technique can be applied to measure the internal benchmark (baseline) price for hectare of any type of land assets, including natural hayland and pastures.

Hence, we conclude that biological and land assets are specific items, being very distinctive in terms of accounting and valuation. The fact complicates the preparation of reliable information on them unless Federal Accounting Standards - Accounting for Biological Assets and Results of Their Biological Transformation, and Accounting for Land Assets are adopted concurrently with the Federal Standards - Fixed Assets and Inventories.

\section{References}

1. Alborov R.A., Kontsevaya S.M. [Development of the methodology for assessing and accounting for biological assets in accordance with IFRS 41 Agriculture]. Mezhdunarodnyi bukhgalterskii uchet = International Accounting, 2012, no. 2, pp. 2-12.

URL: https://cyberleninka.ru/article/n/razvitie-metodiki-otsenki-i-ucheta-biologicheskih-aktivovv-sootvetstvii-s-trebovaniyami-msfo-41-selskoe-hozyaystvo (In Russ.)

2. Kontsevoi G.R. [Improving the methods for assessing and management accounting the material and biological costs in agriculture]. Ekonomika sel'skokhozyaistvennykh i pererabatyvayushchikh predpriyatii = Economy of Agricultural and Processing Enterprises, 2015, no. 1, pp. 26-29. (In Russ.)

3. Kontsevaya S.M., Dzhikiya M.K. [Accounting for biological assets and financial results from their bio-transformation]. Bukhgalterskii uchet $v$ sel'skom khozyaistve = Journal of Accounting in Agriculture, 2018, no. 8, pp. 39-47. (In Russ.)

4. Bodrikova S.V., Mosunova E.L., Zakharova E.V. [Complex assessment of efficiency of strategy in the control system of biological assets and results of their biotransformation]. Vestnik Izhevskoi gosudarstvennoi sel'skokhozyaistvennoi akademii = Bulletin of Izhevsk State Agricultural Academy, 2013, no. 3 (36), pp. 43-46. URL: https://readera.ru/kompleksnaja-ocenkajeffektivnosti-strategii-v-sisteme-upravlenija-14078329 (In Russ.)

5. Dyatlova A.F., Vas'kin F.I. [Operating and investment biological assets: Composition and valuation (status, problems and solutions)]. Mezhdunarodnyi bukhgalterskii uchet $=$ International Accounting, 2015, no. 26, pp. 13-22. URL: https://cyberleninka.ru/article/n/operatsionnye-iinvestitsionnye-biologicheskie-aktivy-sostav-i-otsenka-sostoyanie-problemy-resheniya (In Russ.)

6. Klychova G.S., Zakirova A.R., Klychova A.S., Sitdikova L.F. [Methodological approaches to accounting of biological assets in the cultivation of plants]. Mezhdunarodnyi bukhgalterskii uchet = International Accounting, 2015, no. 23, pp. 14-26.

URL: https://cyberleninka.ru/article/n/metodicheskie-podhody-k-uchetu-biologicheskih-aktivovrastenievodstva (In Russ.)

7. Nurkasheva N.S., Aidynov Z.P., Zharylkasinova M.Zh. [Accounting for biological assets at agricultural enterprises]. Problemy agrorynka, 2019, no. 1, pp. 105-111. (In Russ.)

8. Khusainova A.S. [Accounting of biological assets and agricultural products according to international financial reporting standards]. Vestnik Altaiskogo gosudarstvennogo agrarnogo universiteta $=$ Bulletin of Altai State Agricultural University, 2013, no. 3 (101), pp. 110-116. URL: https://cyberleninka.ru/article/n/buhgalterskiy-uchet-biologicheskih-aktivov-iselskohozyaystvennoy-produktsii-v-sootvetstvii-s-mezhdunarodnymi-standartami (In Russ.) 
9. Shlyapnikova E.A., Vladimirova A.V. [Adaptation of biological assets accounting for agricultural activities management]. Mezhdunarodnyi bukhgalterskii uchet = International Accounting, 2014, no. 11, pp. 32-42. URL: https://cyberleninka.ru/article/n/adaptatsiya-ucheta-biologicheskihaktivov-k-upravleniyu-effektivnostyu-selskohozyaystvennoy-deyatelnosti (In Russ.)

10. Alborov R.A., Kontsevoi G.R., Kontsevaya S.R. [Adaptation of accounting to the requirements of management information system in the agricultural sector]. Vestnik IPB (Vestnik professional'nykh bukhgalterov) $=$ Bulletin for Professional Accountants, 2018, no. 4, pp. 8-16. (In Russ.) URL: https://www.ipbr.org/projects/vestnik/editions/2018/4/alborov-kontsevoy-kontsevaya/

11. Kozmenkova S.V. [The role of accounting in land market management]. Ekonomika sel'skokhozyaistvennykh i pererabatyvayushchikh predpriyatii $=$ Economy of Agricultural and Processing Enterprises, 2003, no. 11, pp. 36-39. (In Russ.)

12. Kozmenkova S.V., Kovanov S.I. [Agricultural land as an accounting item: A historical analysis and contemporary issues]. Mezhdunarodnyi bukhgalterskii uchet = International Accounting, 2015, no. 29, pp. 50-60. URL: https://cyberleninka.ru/article/n/zemli-selskohozyaystvennogonaznacheniya-kak-obekt-ucheta-istoricheskiy-analiz-i-problemy-sovremennosti (In Russ.)

13. Berezinets O.N. [The basic approaches to the definitions of the ground notion as an object of economic relations]. Вісник СевНТУ, 2012, no. 130, pp. 22-29.

URL: http://lib.sevsu.ru:8080/jspui/bitstream/123456789/5500/1/130_04.pdf (In Russ.)

14. Vegera S.G. [Land-fixed capital as an accounting object: composition and classification of land improvements]. Vestnik Polotskogo gosudarstvennogo universiteta. Seriya D: ekonomicheskie i yuridicheskie nauki = Vestnik of Polotsk State University. Part D. Economic and Law Sciences, 2008, no. 10, pp. 100-106. (In Russ.)

15. Vegera S.G. [Accounting for natural resources in the context of the principles of the green economy]. Innovatsionnoe razvitie ekonomiki = Innovative Development of Economy, 2013, no. 3(15), pp. 80-84. (In Russ.)

16. Dauzova A.M. [Land as an accounting object]. Statistika, uchet $i$ audit, 2014, vol. 1, no. 52, pp. 71-76. (In Russ.)

17. Dusaeva E.M., Fedorova O.V. [Criteria and a methodology for assessing land assets in agriculture]. Ekonomicheskii analiz: teoriya i praktika = Economic Analysis: Theory and Practice, 2011, no. 34, pp. 16-21. URL: https://cyberleninka.ru/article/n/kriterii-i-metodika-otsenkizemelnyh-aktivov-v-selskom-hozyaystve (In Russ.)

18. Klychova G.S., Zakirova A.R., Klychova A.S. [Agricultural land management accounting and internal reporting on their use]. Vestnik Kazanskogo gosudarstvennogo agrarnogo universiteta $=$ Bulletin of Kazan State Agrarian University, 2013, vol. 8, no. 4, pp. 15-21.

URL: http://www.vestnik-kazgau.com/images/archive/2013/4/03_klytchova_zakirova.pdf (In Russ.)

19. Khoruzhii L.I., Khusainova A.S. [Improving accounting of land assets]. Bukhgalterskii uchet $v$ sel'skom khozyaistve = Journal of Accounting in Agriculture, 2013, no. 3, pp. 7-12. (In Russ.)

20. Lapteva E.A., Navdaeva S.N. [Rational land use as a factor of agricultural production development]. Ekonomika sel'skokhozyaistvennykh i pererabatyvayushchikh predpriyatii = Economy of Agricultural and Processing Enterprises, 2018, no. 10, pp. 69-73. (In Russ.) 
21. Makht V.A., Rudi V.A., Osintseva N.V. Uchet i otsenka sel'skokhozyaistvennykh zemel' po kachestvu $i$ vidam ispol'zovaniya: monografiya [Accounting and assessment of agricultural land by quality and use: a monograph]. Omsk, Izdatel'skii tsentr KAN Publ., 2018, 72 p.

22. Panin E.V. [Cadastre registry and agricultural land transactions in the Voronezh region at the present stage of development of real estate cadastre]. Vestnik Voronezhskogo gosudarstvennogo agrarnogo universiteta = Vestnik of Voronezh State Agricultural University, 2010, no. 1(24), pp. 95-98. URL: http://vestnik.vsau.ru/wp-content/uploads/2014/12/2010-1-24.pdf (In Russ.)

\section{Conflict-of-interest notification}

We, the authors of this article, bindingly and explicitly declare of the partial and total lack of actual or potential conflict of interest with any other third party whatsoever, which may arise as a result of the publication of this article. This statement relates to the study, data collection and interpretation, writing and preparation of the article, and the decision to submit the manuscript for publication. 